\title{
Prevalensi dan faktor-faktor risiko yang menyebabkan asma pada anak di RSU GMIM Bethesda Tomohon periode Agustus 2011 - Juli 2016
}

\author{
${ }^{1}$ Indri K. T. Runtuwene \\ ${ }^{2}$ Audrey M. I. Wahani \\ ${ }^{2}$ Vivekenanda Pateda
}

\author{
${ }^{1}$ Kandidat Skripsi Fakultas Kedokteran Universitas Sam Ratulangi Manado \\ ${ }^{2}$ Bagian Ilmu Kesehatan Anak Fakultas Kedokteran Universitas Sam Ratulangi Manado \\ Email: indriruntuwene@yahoo.com
}

\begin{abstract}
Asthma is a heterogen disease marked by chronic inflammation in the respiratory tract with a history of disturbance of breathing such as wheezing, dyspnea, and cough. This disease can occur at any age. The etiology of asthma is still unclear but there are various risk factors which can cause asthma inter alia sex, history of atopy, change of weather, dust mites, smoke, pet, and food. This study was aimed to obtain the prevalence of asthma and its risk factors in patients aged 0-18 years at GMIM Bethesda Hospital in Tomohon. This was a descriptive retrospective study. Samples were patients aged 0-18 years admitted at the Pediatric Division of GMIM Bethesda Hospital from August 2011 to July 2016. The results showed that the highest prevalence was from August 2011 to July 2012 (21.62\%) and the risk factors which affected asthma in children were as follows: male (55.41\%), age 5-9 years old $(31.08 \%)$, history of atopy $(52.70 \%)$, and change of weather $(55.40 \%)$. Conclusion: The highest prevalence of ashmatic patients was $21.62 \%$ from August 2011 to July 2012. The majority of risk factors were male sex, change of weather, history of atopi, and dust mites.
\end{abstract}

Keywords: asthma, prevalence, risk factor, children

\begin{abstract}
Abstrak: Asma merupakan penyakit heterogen yang biasanya ditandai oleh peradangan kronik pada saluran napas dengan riwayat gejala pernapasan seperti mengi, sesak napas, dan batuk yang dapat terjadi pada semua kelompok usia. Etiologi asma masih belum jelas namun terdapat berbagai faktor risiko yang dapat memicu terjadinya asma seperti jenis kelamin, usia, riwayat atopi, perubahan cuaca, tungau debu rumah, paparan asap rokok, binatang piaraan, dan makanan. Penelitian ini bertujuan untuk mengetahui prevalensi asma dan faktorfaktor risiko yang memengaruhi terjadinya athat the highest prevalence wassma di RSU GMIM Bethesda Tomohon. Jenis penelitian ialah deskriptif retrospektif. Sampel penelitian ialah pasien anak usia 0-18 tahun dengan diagnosis utama asma yang dirawat di Bagian Ilmu Kesehatan Anak RSU GMIM Bethesda Tomohon pada periode Agustus 2011-Juli 2016. Hasil penelitian menunjukkan prevalensi terbanyak pada periode Agustus 2011-Juli 2012 $(21,62 \%)$ dan faktor risiko yang memengaruhi asma pada anak berupa jenis kelamin laki-laki $(55,41 \%)$, usia 5-9 tahun $(31,08 \%)$, riwayat atopi $(54,05 \%)$, tungau debu rumah $(52,70 \%)$, dan perubahan cuaca $(55,40 \%)$. Simpulan: Kejadian asma terbanyak terjadi pada periode Agustus 2011-Juli 2012 sebesar 21,62\%. Faktor risiko tersering ditemukan ialah jenis kelamin laki-laki, perubahan cuaca, riwayat atopi, dan tungau debu rumah.
\end{abstract}

Kata kunci: asma, prevalensi, faktor risiko, anak

Asma merupakan penyakit heterogen yang biasanya ditandai dengan peradangan pada saluran napas yang bersifat kronik dengan ditemukannya riwayat gejala pernapasan seperti mengi, sesak napas, sesak dada, dan batuk. Asma juga merupakan masalah 
kesehatan dunia yang serius yang memengaruhi semua kelompok usia, mulai dari anak-anak sampai dengan dewasa yang memiliki banyak dampak buruk baik terhadap pasien sendiri, keluarga, maupun masyarakat. ${ }^{1,2}$ Berdasarkan hasil Riset Kesehatan Dasar (Riskesdas) di Indonesia tahun 2013 didapatkan prevalensi asma di Indonesia 4,5\% dengan kejadian terbanyak pada perempuan sebesar $4,6 \%$. Prevalensi asma tertinggi terdapat di Sulawesi Tengah $(7,8 \%)$, diikuti Nusa Tenggara Timur $(7,3 \%)$, DI Yogyakarta $(6,9 \%)$, dan Sulawesi Selatan $(6,7 \%)$. Sulawesi Utara masuk ke urutan 18 dari 33 provinsi dengan prevalensi sebesar 4,7\%. Prevalensi asma pada anak yang tertinggi di usia 5-14 tahun sebesar $3,9 \% .^{3}$ Prevalensi asma pada anak telah meningkat di sebagian negara maju, meskipun prevalensi telah mulai menurun di negara-negara barat. Etiologi dari asma sampai saat ini masih belum jelas tetapi terdapat berbagai faktor-faktor risiko yang dapat menyebabkan terjadinya asma. Asma masa anak-anak sangat terkait dengan alergi, tetapi beberapa hal juga dapat memicu asma seperi asap rokok, udara, dan infeksi saluaran pernapasan. ${ }^{4,5}$ Penelitian ini bertujuan untuk mengetahui prevalensi dan faktor- faktor risiko yang menyebabkan asma pada anak di RSU GMIM Bethesda Tomohon periode Agustus 2011 - Juli 2016.

\section{METODE PENELITIAN}

Jenis penelitian ialah deskripstif retrospektif yang dilakukan di Bagian Rekam Medik RSU GMIM Bethesda Tomohon bulan September sampai November 2016. Sampel penelitian ialah pasien anak dengan diagnosis asma yang dirawat di Bagian Ilmu Kesehatan Anak RSU GMIM Bethesda Tomohon pada periode Agustus 2011-Juli 2016. Pengambilan sampel disesuaikan dengan kriteria inklusi yaitu anak dengan diagnosis utama asma usia 0-18 tahun. Data diolah dengan menggunakan Microsoft Excel 2007.

\section{HASIL PENELITIAN}

Distribusi frekuensi pasien asma berdasarkan tahun mendapatkan pada periode Agustus 2011-Juli 2012 sejumlah 16 pasien (21,62\%); Agustus 2012-Juli 2013 terdapat 15 pasien $(20,27 \%)$; Agustus 2013-Juli 2014 terdapat 14 pasien (18,92\%); Agustus 2014-Juli 2015 terdapat 14 pasien (18,92\%); dan Agustus 2015-Juli 2016 terdapat 15 pasien $(20,27 \%)$. Keseluruhan pasien asma yang berusia 0-18 tahun yang dirawat di RSU Bethesda Tomohon dari periode Agustus 2011-Juli 2016 sebanyak 74 pasien (Tabel 1).

Tabel 1. Distribusi frekuensi berdasarkan tahun

\begin{tabular}{ccc}
\hline Tahun & n & $\mathbf{( \% )}$ \\
\hline Agustus 2011-Juli 2012 & 16 & 21,62 \\
Agustus 2012-Juli 2013 & 15 & 20,27 \\
Agustus 2013-Juli 2014 & 14 & 18,92 \\
Agustus 2014-Juli 2015 & 14 & 18,92 \\
Agustus 2015-Juli 2016 & 15 & 20,27 \\
Total & 74 & 100 \\
\hline
\end{tabular}

Distribusi pasien anak dengan asma berdasarkan jenis kelamin didapatkan 41 pasien laki-laki $(55,41 \%)$ dan 33 pasien perempuan $(44,59 \%)$ (Tabel 2$)$.

Tabel 2. Distribusi pasien anak dengan asma berdsarkan jenis kelamin

\begin{tabular}{ccc}
\hline Jenis kelamin & n & $(\mathbf{\% )}$ \\
\hline Laki - laki & 41 & 55,41 \\
Perempuan & 33 & 44,59 \\
Total & 74 & 100 \\
\hline
\end{tabular}

Distribusi frekuensi berdasarkan usia mendapatkan yang terbanyak pasien berusia 5-9 tahun berjumlah 23 pasien $(31,08 \%)$ diikuti yang berusia $0-4$ tahun sebanyak 22 pasien $(29,72 \%)$ (Tabel 3).

Tabel 3. Distribusi frekuensi berdasarkan usia

\begin{tabular}{ccc}
\hline Usia & $\mathbf{n}$ & $\mathbf{( \% )}$ \\
\hline $0-4$ tahun & 22 & 29,72 \\
$5-9$ tahun & 23 & 31,08 \\
$10-14$ tahun & 11 & 14,87 \\
$15-18$ tahun & 18 & 24,33 \\
Total & 74 & 100 \\
\hline
\end{tabular}

Distribusi pasien berdasarkan faktor risiko riwayat atopi dalam keluarga mendapatkan 40 pasien $(54,05 \%)$ dengan 
riwayat atopi dan 34 pasien $(45,95 \%)$ tanpa riwayat atopi dalam keluarga.

Tabel 4. Distribusi pasien berdasarkan faktor risiko riwayat topi dalam keluarga

\begin{tabular}{ccc}
\hline Riwayat Atopi & $\mathbf{n}$ & $\mathbf{( \% )}$ \\
\hline Ada & 40 & 54,05 \\
Tidak ada & 34 & 45,95 \\
Total & 74 & 100 \\
\hline
\end{tabular}

Distribusi pasien berdasarkan faktor risiko tungau debu rumah mendapatkan 39 pasien $(52,7 \%)$ dengan faktor risiko tersebut dan 35 pasien $(47,3 \%)$ tanpa faktor risiko tersebut.

Tabel 5. Distribusi pasien berdasarkan faktor risiko tungau debu rumah (TDR)

\begin{tabular}{lll}
\hline TDR & $\mathbf{n}$ & $\mathbf{( \% )}$ \\
\hline Ada & 39 & 52,70 \\
Tidak ada & 35 & 47,30 \\
Total & 74 & 100 \\
\hline
\end{tabular}

Distribusi pasien berdasarkan faktor risiko perubahan cuaca mendapatkan 41 pasien $(55,4 \%)$ memiliki faktor risiko tersebut dan 33 pasien $(44,6 \%)$ tidak memilki faktor risiko tersebut.

Tabel 6. Distribusi pasien berdasarkan faktor risiko perubahan cuaca

\begin{tabular}{ccc}
\hline $\begin{array}{c}\text { Alergi cuaca } \\
\text { dingin }\end{array}$ & $\mathbf{n}$ & $\mathbf{( \% )}$ \\
\hline Ada & 41 & 55,40 \\
Tidak ada & 33 & 44,60 \\
Total & 74 & 100 \\
\hline
\end{tabular}

\section{BAHASAN}

Berdasarkan dari hasil penelitian yang dilakukan di RSU GMIM Bethesda Tomohon melalui pengambilan rekam medik didapatkan pasien asma pada anak yang berusia 0-18 tahun pada periode Agustus 2011-Juli 2012 yang memenuhi kriteria inklusi berjumlah 74 pasien.

Dari pengolahan data yang didapatkan bahwa jumlah kasus asma mengalami penurunan setiap tahunnya. Dari Agustus 2011-Juli 2014 terjadi penurunan kasus asma. Pada Agustus 2014-Juli 2015 tidak terjadi perubahan baik penurunan atau peningkatan kasus asma tetapi pada periode Agustus 2015-Juli 2016 terjadi peningkatan kembali kasus asma pada anak.

Berdasarkan jenis kelamin pasien lakilaki berjumlah lebih banyak dari pada pasien perempuan Hasil ini serupa dengan hasil penelitian dari Dumbi et al. ${ }^{6}$ tahun 2013 yang menunjukkan bahwa prevalensi asma lebih tinggi pada anak laki-laki. Hal itu disebabkan karena diameter saluran pernapasan anak laki-laki lebih sempit dibandingkan anak perempuan sehingga kepekaagi bila terjadi obstruksi atau penyumbatan. ${ }^{6,7}$

Berdasarkan kelompok usia, angka kejadian asma tertinggi terjadi pada kelompok usia 5-9 tahun. Hal ini selaras dengan data dari Centers for Disease Control and Prevention (CDC) ${ }^{8}$ tahun 2013 yang menunjukkan kejadian asma terbanyak pada kelompok usia 5-9 tahun.

Berdasarkan faktor risiko adanya riwayat atopi terdapat 40 pasien $(54,5 \%)$ dengan riwayat atopi dalam keluarga. Penelitian ini sejalan dengan penelitian Mangguang $^{9}$ yang mendapatkan bahwa kebanyakan anak dengan asma memilki riwayat atopi dalam keluarga. Penelitian tersebut dilakukan pada 32 anak dan terdapat 23 anak $(71,9 \%)$ dengan riwayat atopi. Dari situ dapat dilihat bahwa faktor risiko adanya riwayat atopi memiliki peran yang besar akan terjadinya asma. ${ }^{9}$

Berdasarkan faktor risiko adanya pengaruh tungau debu rumah terhadap kejadian asma didapatkan sebanyak 39 anak $(52,70 \%)$. Hasil penelitian ini tidak sejalan dengan penelitian Purnomo ${ }^{10}$ yang menyatakan debu tidak terlalu berpengaruh terhadap terjadinya episode asma tetapi sejalan dengan penelitian oleh Dumbi et al. ${ }^{6}$ yang melaporkan terdapat $33(66 \%)$ dari 50 penderita mengalami alergi terhadap tungau debu. Hal tersebut disebabkan masuknya alergen berupa debu menyebabkan terjadinya reaksi hipersensitivitas tipe $1 .^{6,10,11}$

Berdasarkan faktor risiko adanya pengaruh perubahan cuaca atau cuaca dingin terhadap kejadian asma ditemukan 
sebanyak 41 pasien $(55,40 \%)$. Faktor risiko ini merupakan yang tertinggi terhadap terjadinya kekambuhan asma pada anak di RSU GMIM Bethesda Tomohon. Hal itu mungkin disebabkan karena lokasi Kota Tomohon yang terletak di dataran tinggi dengan iklim atau cuaca yang dingin. Penelitian ini tidak sejalan dengan penelitian Husein dan Ahmed ${ }^{12}$ yang mengatakan bahwa pengaruh debu lebih besar daripada pengaruh cuaca dingin. Hasil penelitian ini sejalan dengan penelitian yang dilakukan oleh Usman et al. ${ }^{12}$ yang menunjukkan bahwa perubahan cuaca atau cuaca dingin memiliki hubungan yang sangat besar terhadap kejadian asma yaitu terdapat $29(65,91 \%)$ dari 44 pasien.

\section{SIMPULAN}

Berdasarkan hasil penelitian dapat disimpulkan bahwa prevalensi tertinggi terjadinya asma pada anak di RSU GMIM Bethesda Tomohon terjadi pada periode Agustus 2011-Juli 2012. Riwayat atopi, tungau debu, dan perubahan cuaca atau udara dingin berpengaruh besar terhadap kejadian episodik asma

\section{SARAN}

1. Diperlukan edukasi dari pihak kesehatan agar orang tua lebih memahami faktor risiko asma sehingga orang tua selalu memperhatikan lingkungan sekitar dari anak dengan asma

2. Diperlukan perhatian khusus dari orang tua terhadap lingkungan di rumah, sekolah, maupun lingkungan bermain dari anak yang memiliki riwayat asma.

3. Diperlukan perhatian dari pihak sekolah untuk menjaga lingkungan belajar maupun bermain karena anak dengan asma peka terhadap alergen di lingkungan sekitar.

\section{DAFTAR PUSTAKA}

1. Global Initative for asthma. Global stategy for asthma management and prevention. 2016. Available from: www.ginasthma.org

2. Reddel KH, Bateman ED, Becker A, Boulet
LP, Cruz AA, Drazen JM, et al. A summary of the GINA strategy: a roadmap to asthma control. Eur Respir J. 2015;46(3):622-39

3. Lochte L, Nielsen KG, Petersen PE, PlattsMills TA. Childhood asthma and physical activity: a systematic review with meta-analysis and graphic appraisal tool for epidemiology assesment. C Pediatr. 2016;16:50

4. Papadopoulus NG, Arakwa H, Carlsen KH, Custovic A, Gern J, Lemanske R, et al. International consensus on (ICON) pediatric asthma. Allergy. 2012;67(8): 976-97.

5. Riset kesehatan dasar 2013. Jakarta: Balitbang Kesehatan Kemenkes RI, 2013.

6. Dumbi SAN, Saraswati D, Prasetya E. Faktor risiko penyebab asma bronkial. Gorontalo: Department of Public Health, Faculty of Sports and Health Sciences, Universitas Negeri Gorontalo; 2013.

7. Dharmayanti I, Hapsari D, Azhar K. Asma pada anak di Indonesia: penyebab dan pencetus. Jurnal Kesehatan Masyarakat Nasional. 2015;9:320-6

8. Centers for disease control and prevention. Asthma. 2014 [updated March 25, 2013. [cited 2014 February 1]; Available from: http://www.cdc.gov/ asthma/asthmadata.html

9. Mangguang M. Faktor risiko kejadian asma pada anak di kota Padang. Arc Com health. 2016;3(1):1-7

10. Purnomo, Hadisaputro S, Zain MS. Faktorfaktor risiko yang berpengaruh terhadap kejadian asma bronkial pada anak. Semarang: Universitas Diponegoro; 2008.

11. Danusaputro H. Ilmu Penyakit Paru. Bandung: Bina Cipta, 2000; p. 197209.

12. Husein SE, Ahmed MA. Prevalence and risk factors of asthma among Wad Medani basic school children, Gezira state, Udan. J Fam Com Med. 2005;12(3): 145-8.

13. Usman I, Chundrayetti E, Khairsyaf $O$. Faktor risiko dan faktor pencetus yang mempengaruhi kejadian asma pada anak di RSUP Dr. M. Djamil Padang. Jurnal Kesehatan Andalas. 2015;4:3927. 